\title{
SOME MEMORABLE FACULTY MEMBERS AT PACIFIC UNIVERSITY COLLEGE OF OPTOMETRY IN THE EARLY 1970s
}

\section{David A. Goss, OD, PhD \\ Emeritus Professor of Optometry Indiana University \\ dgoss@indiana.edu}

This article will discuss three of our instructors in optometry school at Pacific University in the early 1970s. These three had in common the characteristic of using somewhat idiosyncratic or attention-getting verbal expressions.

\section{Charles Boyd Margach (1912-1988)}

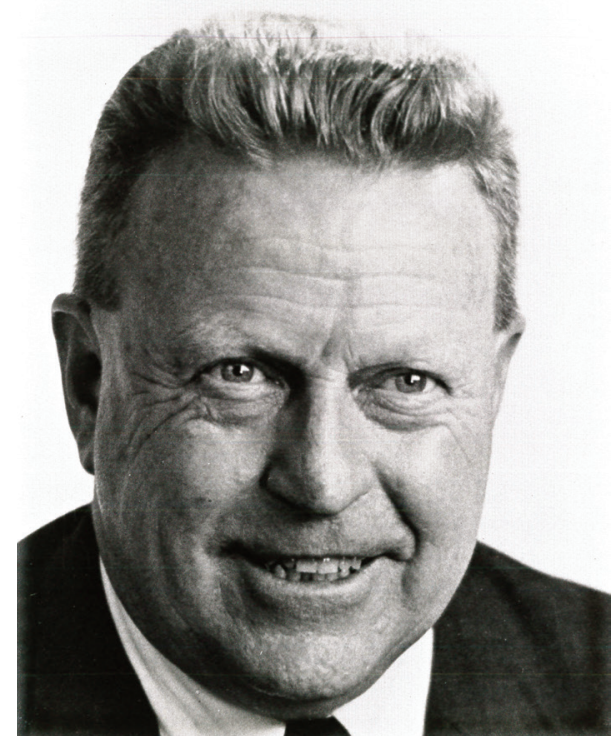

Charles B. Margach (photo courtesy of Southern California College of Optometry).

Charles B. (Charley) Margach was born in Utica, New York. The 1930 federal census shows 17-year-old Charles Margach living with his parents in Utica and employed as a journalist. In the 1940 federal census, 27-year-old Charles Margach is living in Euclid, Ohio and working as an office clerk in the office equipment industry. After service in the United States Navy during World War II, he attended the Northern Illinois
College of Optometry, completing the Doctor of Optometry degree in 1948. Margach joined the faculty at Pacific University in 1948 and completed B.S. (1950) and M.S. (1951) degrees while a member of the faculty. He served on the faculty at Pacific until 1973, when he went to Southern California College of Optometry (SCCO), from which he retired in 1987.2

Over his career, Margach taught courses in several different areas, including geometric optics, examination procedures, case analysis, optometric theory, ophthalmic optics, and low vision. ${ }^{2}$ He was the instructor in two courses for our class, Optometry I and Optometry II, which were largely devoted to management of refractive problems, lens prescribing, and the Optometric Extension Program (OEP) check, chain, and type procedure for analysis of the 21-point examination.
Low vision was also covered in a portion of the second course.

Among other duties that Margach had for various periods of time were Clinic Director at Pacific and Director of the Optometric Technician program at SCCO. He was active in several optometric organizations, serving as president of the Oregon Optometric Association in 1969-70, editor of the Oregon Optometrist, and editor of the Journal of the American Optometric Association for a brief time in the 1960s. Margach was particularly active in OEP. He was editor for OEP's education curricula from 1983 to 1988, and wrote extensively for OEP, authoring a series of literature and research reviews from 1973 to 1988. Some of his articles for OEP were collected in bound volumes on optometric testing procedures and low vision, some of which we used for

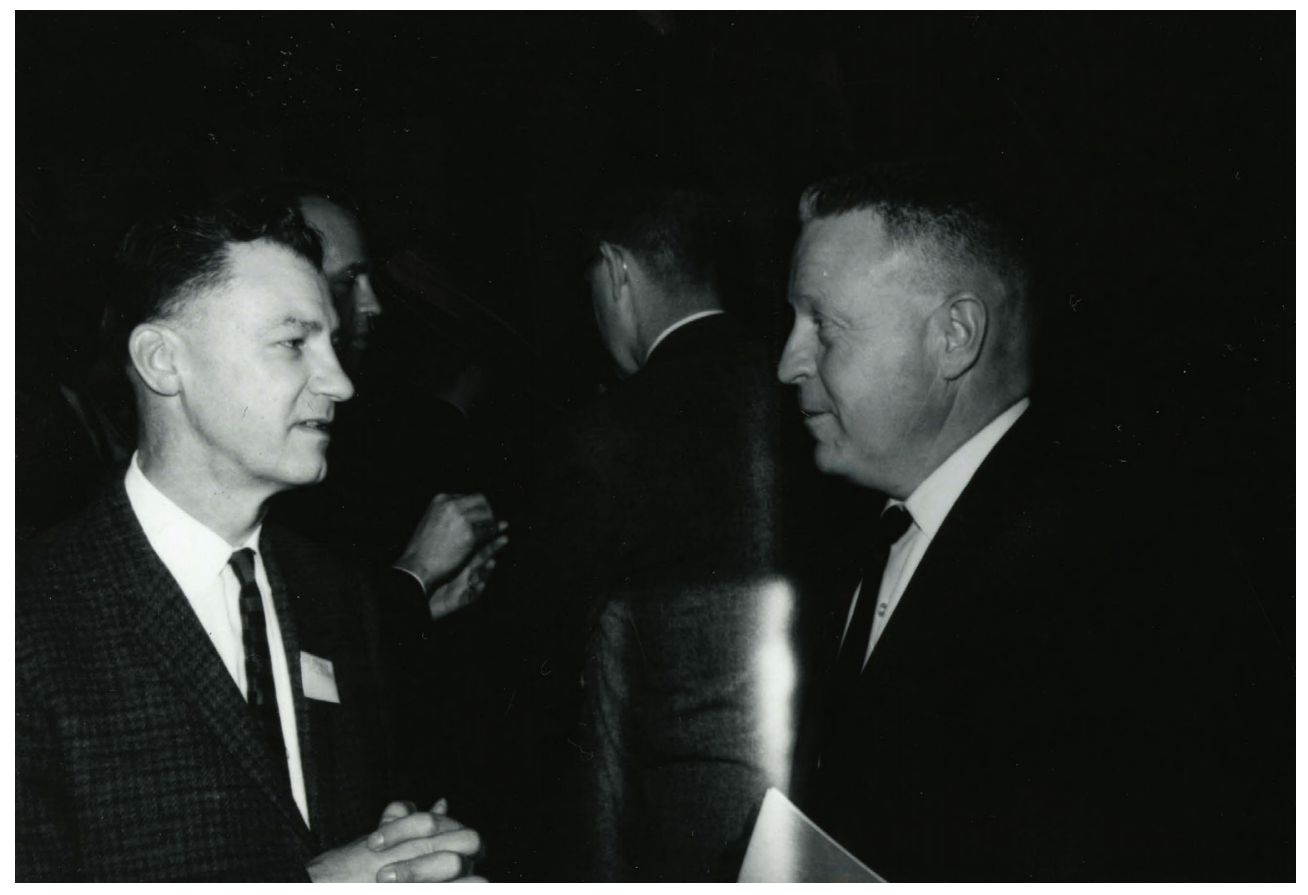

Charles Margach (right) in conversation with Roy Stealey of Optometric Weekly at the American Academy of Optometry meeting in 1964 (photo courtesy of Archives and Museum of Optometry) 
reference texts. In 1979, OEP published his short monograph Introduction to Functional Optometry.

In the 1970s and earlier, there was sometimes tension between advocates of OEP and other schools of thought in optometry, and Margach as a staunch follower of OEP seemed to fan the flames at times. In degrading tones he referred to some who had viewpoints opposed to his as geometricians and p-ometricians. Margach was strict about semantics, terminology, and proper pronunciation. He emphasized that the words monocular and binocular should not be pronounced mōnocular and by-nocular, but rather mon-ocular and bin-ocular. He said that the root word was ocular; there was no such thing as a nocular.

Margach used acronyms to describe different philosophies of lens prescribing. COW stood for conventional optometric wisdom. CRE was an acronym for correct the refractive error. And RNS meant relieve the nearpoint stress. In discussing cases, he would talk about what the CRE man would do and what the RNS man would do (this was a time when there were very few women in optometry and none in our class). It was clear that he thought COW was important, CRE was simplistic but often necessary, and RNS was the highest form of care. Charley Margach was occasionally entertaining, sometimes obscure, always opinionated, and a significant part of our education.
Colin B. Pitblado (1939-2002)

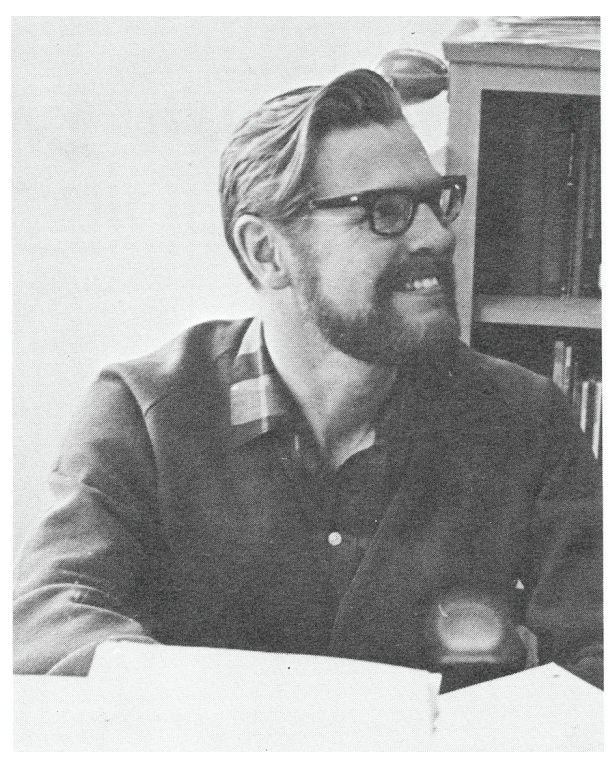

Colin Pitblado (photo from 1971 Pacific

University yearbook, page 19).

In the early 1970s, Pacific University's optometry curriculum was strong in vision training, including background courses in experimental, developmental, visual, and physiological psychology. One of the instructors in those courses was Colin Pitblado. Pitblado received his B.A. degree from the University of Connecticut in 1961, and completed A.M. (1963) and Ph.D. (1966) degrees from Boston University. ${ }^{3}$ His Ph.D. degree was in experimental psychology and his dissertation title was Displacement of half-images during binocular vision. ${ }^{4}$ During his career he published papers on visual perception and stereopsis in various psychology and perception journals.

Pitblado taught in the College of Optometry and the Department of Psychology at Pacific University. He was on the faculty at Pacific from 1966 to 1976. He recalled that: "My first six years teaching here was in the College of Optometry. I just got out of my graduate program at Boston University, and many of my first students were my same age. We had a great time together." ${ }^{\prime 5}$ Scott Pike, a member of the Pacific University Optometry Class of 1970, recalled that he barely beat Pitblado to take fourth place in the campus intramural 440 yard race. ${ }^{6}$ Pitblado had a youthful appearance, so he seemed close in age to optometry students even after his first few years at Pacific.

In 1976, Pitblado left Pacific to go to the University of Connecticut Institute of Living in Hartford, Connecticut to do research in visual orientation. ${ }^{5}$ Later he was on the psychology faculty at Post College in Waterbury, Connecticut, when he died of cancer. ${ }^{7}$

I remember that Pitblado had a habit of saying "i.e.," abbreviation for id est, meaning "that is (to say)" during his lectures. That expression may be somewhat common in written language, but it is not common in verbal language, so it got our attention when he said it. We started a pool with guesses of how many times he would say "i.e." in each lecture. He must have heard that we were doing that because one day he did not say it and then didn't the rest of the semester. We didn't get to know Colin Pitblado as well as we did some instructors with whom we worked in clinic or with whom we had more courses, but he was well-liked and was respected for his knowledge of visual perception.

\section{Don Corlis West (1923-2017)}

Don C. West was born and raised in Anna, Illinois, a small town in southern Illinois, not far from the Kentucky and Missouri borders. He attended Carthage College for two years before enlisting in the U.S. Army in 1943. ${ }^{8}$ After discharge from the Army in 1946, he married Jean Wahl, the daughter of Anna, Illinois optometrist James Wahl. James Wahl (1901-1982) was president of the American Optometric Association (AOA) in 1952-54. The first 
administrative headquarters of the AOA was a room added on to Wahl's office in Anna. ${ }^{9}$ Wahl practiced in Anna until 1955, when Don West took over the practice. From 1955 to 1963, Wahl was Dean of the Pacific University College of Optometry. ${ }^{10}$

Don West received his O.D. degree in 1949 from Southern College of Optometry. ${ }^{11}$ After graduation he practiced in Anna, until in 1958, he moved to Forest Grove to teach at Pacific University. ${ }^{8}$ He was an optometry professor at Pacific for over 30 years. He taught contact lens courses and was in charge of contact lens fitting in the clinic. He was a member of the Association of Optometric Contact Lens Educators, and in 1984, he participated in their John DeCarle Visiting Professorship program funded by Cooper Vision, lecturing at several optometry schools in Great Britain. ${ }^{12}$

West often used folksy expressions to make points in his lectures. A poorly fitted contact lens might result in a patient "blinking like a toad in a

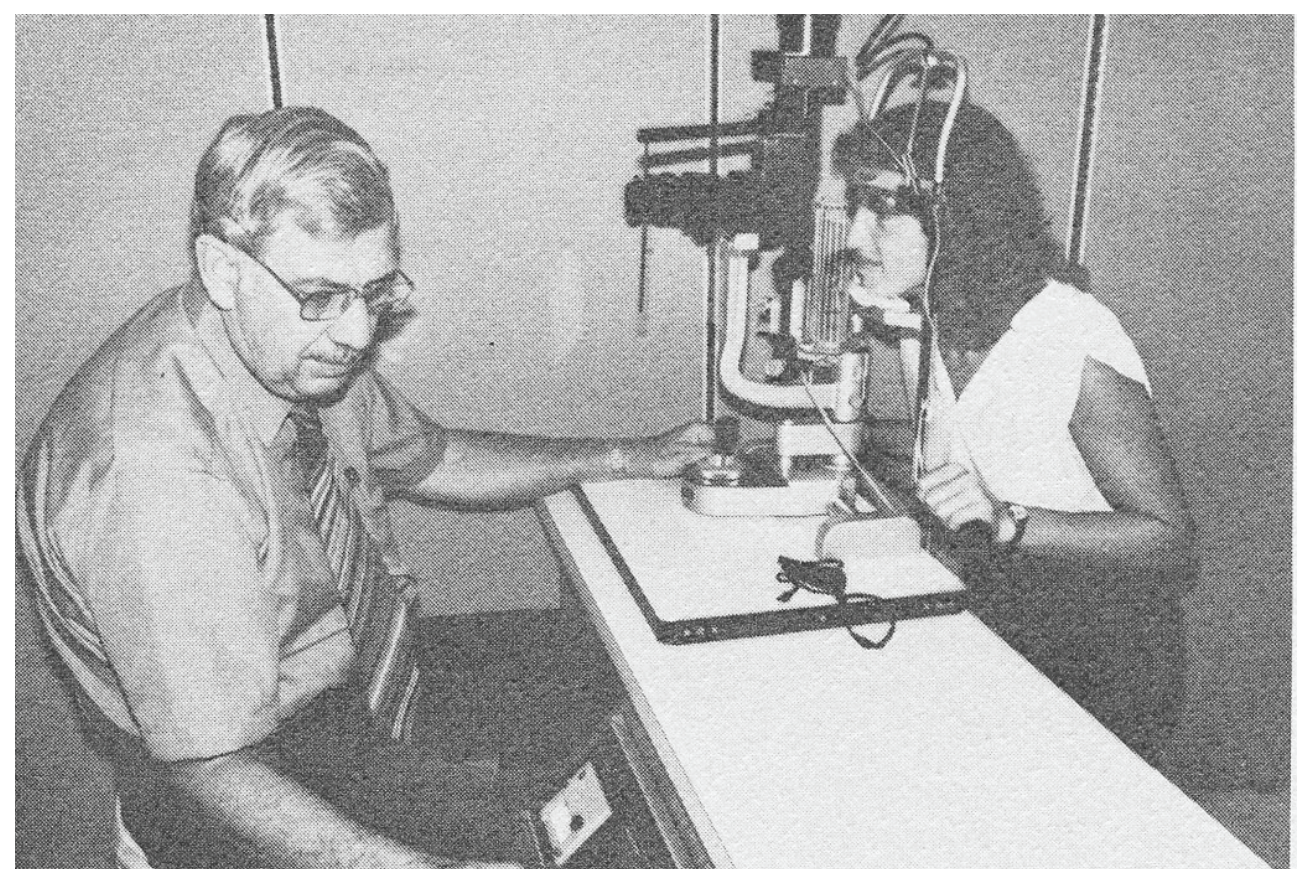

Don C. West (photo from College of Optometry Research Programs, undated Pacific University pamphlet). hail storm." A contact lens which did not move enough might be "tighter than bark on a tree."West had a good knowledge of basic optometry as well as contact lenses. For example, he knew that myopic patients had to accommodate more with contact lenses than with spectacles, pushing them into greater esophoria at near. He warned that patients with myopia and a significant near esophoria would "fall apart like staves on a barrel with the hoops off" when wearing contact lenses. He also sometimes talked about topics other than contact lenses. For example, he noted that if a bifocal segment was too high in spectacles, the patient might be "stepping like a chicken in tall oats." I remember Don West as having a pleasant jovial demeanor, while maintaining high standards in his class and in advising in the clinic. Scott Pike who, as well as being a Pacific alumnus, has served on was "happy and jolly as ever" in his later years. ${ }^{\circ}$ the Pacific faculty, said that Don West

\section{References}

1. Directory of the American Optometric Association. St. Louis: American Optometric Association, 1972:226.

2. In Memoriam Charles Boyd Margach, B.S., M.S., O.D. Mailing from Optometric Extension Program to members, February 23, 1988.

3. Pacific University Bulletin 69-70. Forest Grove, OR: Pacific University, 54(1):178.

4. OCLC WorldCat library catalog. www.worldcat.org.

5. Pacific University Index. Feb. 27, 1976;87(16):1. https://news.google. com. Retrieved Sept. 9, 2015.

6. Pike S. Email to the author, Nov. 22, 2017.

7. Dr. Colin B. Pitblado. Hartford Courant. June 15, 2002. http:// articles.courant.com. Retrieved Sept. 9, 2015.

8. Don C. West Obituary. Fuiten Rose \& Hoyt Funeral Home. www. fuitenrosehoyt.com/obituary/DonC-West/Forest-Grove-OR/1701319. Retrieved Nov. 4, 2017.

9. Gregg JR. American Optometric Association - A History. St. Louis: American Optometric Association, 1972:237-239.

10. Directory of the American Optometric Association. St. Louis: American Optometric Association, 1972:365.

11. Pacific University College of Optometry Bulletin 68-69. Forest Grove, OR: Pacific University, 1968:24-25.

12. AOCLE History. Association of Contact Lens Educators. www. aocle.org/history.html. Retrieved Sept. 2, 2015. 